\title{
TÃO FELIZES, NUNCA FOMOS: LITERATURA E CINEMA EM TEMPOS DE AUTORITARISMO
}

\section{NEVER THAT HAPPY: LITERATURE AND CINEMA IN TIMES OF AUTHORITARIANISM}

\author{
João Manuel dos Santos Cunha*
}

RESUMO: O texto examina a tradução intersemiótica operada pelo cineasta Murilo Salles para o conto de João Gilberto Noll "Alguma coisa urgentemente" (1980), denominada Nunca fomos tão felizes (1984), considerando o contexto da ditadura civil-militar brasileira (19641985), período em que as duas narrativas foram criadas. Reflete, ainda, sobre o fato de que as representações literária e fílmica, em conjunto ou separadamente, podem ser lidas como "lugares de memória" (lieux de mémoire, conceito proposto por Pierre Nora, 1991): textos que, ao cumprirem o ofício de lembrar, revelam o possível papel das artes como sendo o de traduzir em discurso fatos que resistem à apreensão até mesmo pelo enunciado explicativo e relativizante da história.

PALAVRAS-CHAVE: literatura e cinema, literatura e autoritarismo, tradução intersemiótica, transtextualidade.

ABSTRACT: This article examines the intersemiotic translation of a short story by João Gilberto Noll ("Alguma coisa urgentemente", 1980) into a film by Murilo Salles (Nunca fomos tão felizes, 1984), considering the context of the civil and military dictatorship in Brazil (1964-1985), when the story was written and the film made. It also reflects on the fact that the literary and the filmic representations, seen both together and separately, may be read as lieux de mémoire (according to a concept proposed by Pierre Nora, 1991). Those are texts that, as they perform the task of remembering, may be seen as a comment on the possible role of the arts in translating into discourse facts that resist understanding, even by the explanatory and relativizing enunciation of history.

KEYWORDS: literature and cinema, literature and authoritarianism, intersemiotic translation, transtextuality.

\footnotetext{
* Doutor em Letras - Literatura Comparada, UFRGS; possui pós-doutorado em Literatura e Cinema, Sorbonne-Nouvelle, Paris III; Professor Adjunto de Literatura Brasileira; Literatura Comparada; Teoria e Crítica Literária, em Graduação e Pós-Graduação em Letras; Faculdade de Letras, Departamento de Letras Vernáculas, Universidade Federal de Pelotas, RS.profjoaomanuel@ terra.com.br.
} 



\section{INTRODUÇÃO}

O objetivo deste ensaio é avançar na reflexão sobre a prática comparatista, instalando o tema no espaço da tradução de narrativas literárias para o cinema, por meio da discussão sobre a natureza das relações intertextuais e interculturais, vistas no contexto da interdisciplinaridade, com a aproximação de textos literários e fílmicos. Por conta dessa visada, está implícito o fato incontornável de que toda leitura de objetos culturais e estéticos implica produção de sentido por um leitor específico: cada receptor da mensagem interpreta o texto a partir de seu horizonte de expectativas, ${ }^{1}$ inserido que está em contexto histórico determinado.

Para tanto, pensando estratégias interdisciplinares por via de reforços teóricos aportados por diversos campos do conhecimento, valhome do resultado de discussões encetadas por teóricos da narratologia fílmica, como Christian Metz e André Gaudreault, e de semiólogos,

\footnotetext{
${ }^{1}$ Uso a expressão "horizonte de expectativas" no sentido gadameriano: "Um horizonte não é uma fronteira rígida, mas algo que se desloca com a pessoa e que convida a que se continue penetrando" (GADAMER, 2003: 373). Para ele, na relação obra-receptor há sempre um devir entre antecipação e retrospecção, no qual o leitor oscila entre a estrutura do texto e o seu próprio imaginário; é essa fusão de horizontes de expectativa que forma um horizonte provisório, no qual o leitor produz sentido para o que lê.
} 
como Haroldo de Campos, ${ }^{2}$ para a aplicação de conceitos relativos ao estatuto do narrador fílmico e da própria condição de texto referida à narrativa literária na sua comparação com a imagética. Considera-se que os paradigmas teóricos alcançados por esses investigadores sejam ainda incontornáveis para os estudos comparados entre literatura e cinema, ainda que, contemporaneamente, tenham sido reprocessados, com avanços incontestáveis, no campo das relações intermidiáticas, por meio de reflexões que resultaram em construções teóricas consequentes, como a da teoria da intermidialidade, desenvolvida por Claus Clüver. ${ }^{3}$

Por outro lado, como aponta Rita Schmidt, a literatura comparada, longe de ignorar que o seu objeto de reflexão é o texto literário, coloca sua razão de ser no comprometimento em direção ao outro, "a outro texto, a outra literatura, a outra história, a outra cultura". (2007: 28) Nesses termos, ainda que "o discurso literário seja um discurso particular - mas não um discurso

\footnotetext{
${ }^{2}$ É pacífica a ideia, na teoria fílmica contemporânea, de que o texto fílmico tem autonomia de código narrativo textual, principalmente após as reflexões desenvolvidas a partir dos anos sessenta por Christian Metz (1980: 338): “O cinema não é uma língua, sem dúvida nenhuma, mas pode ser considerado como uma linguagem, na medida em que ordena elementos significativos no seio de combinações reguladas, diferentes daquelas praticadas pelos idiomas e que tampouco decalcam a realidade. Assim, sendo uma linguagem, permite uma escrita, isto é, o texto fílmico." Essa reflexão repercute entre a crítica cinematográfica e literária, gerando aplicação importante no meio dos estudos comparados que se ocupam das relações entre palavra e imagem, por pesquisadores como André Gaudreault (1988), Jeanne-Marie Clerc (1985, 1993), Francis Vanoye (1989) ou Michel Serceau (1999). No Brasil, é com Haroldo de Campos (1969) que tal ideia vai avançar com consequências incontornáveis no âmbito dos estudos semiológicos acadêmicos. Sobre a questão, ainda não completamente resolvida, do narrador fílmico face ao estatuto do narrador literário, devo recuperar dois posicionamentos teóricos importantes: de acordo com Genette (1982: 102, tradução minha), "há na narração, ou ainda, atrás ou na frente dela, alguém que narra: é o narrador. Além do narrador, há alguém que escreve e que é responsável por tudo; isto é, o autor; e isso me parece, já dizia Platão, suficiente”. Para Laffay (1964: 81, tradução minha), "o narrador fílmico é aquela presença virtual escondida atrás de todos os filmes: le grand imagier". André Gaudreault (1988: 11), ampliando as propostas de Genette e Laffay, propõe a seguinte comparação para o estatuto dos dois narradores: "Récit scriptural: auteur (écrivain), auteur implicite, abstrait, narrateur scriptural; récit filmique: auteur (cinéaste), le grand imagier, narrateur filmique, articulateur du plan à plan, montateur." Como se vê, nessa articulação, são apagadas as diferenças de códigos para que permaneçam definidas as figuras do narrador literário (narrateur scriptural) e narrador fílmico (narrateur filmique, le grand imagier).

${ }^{3}$ Para outras informações sobre o conceito de intermidialidade, ver "Estudos interartes: conceitos, termos, objetivos" (1997) de Claus Clüver.
} 
à-parte" -, nele, "o contexto se refrata em forma de texto", como observou Leyla Perrone-Moisés (2001: 7). O permanente movimento que revitaliza o comparatismo e que lhe dá uma nova configuração é, justamente, na direção em que aponta Tania Franco Carvalhal, o "vaivém entre campos e textos, literários ou não; entre noções e seus avessos; entre o teórico e o imaginário" (2005: 170).

Na esteira dos movimentos teórico-críticos da Desconstrução, da Nova História e dos chamados Estudos Culturais e Pós-Coloniais, a literatura comparada conformou-se em uma "dimensão que se expressa hoje pela multiplicidade de caminhos com que ela dialoga com a obra literária" (COUTINHO, 2007: 25). Por outro lado, estabilizou-se, em escala mundial, uma tendência a considerar todos os objetos culturais como cultura popular, com a consequência inevitável da mudança de paradigmas teóricos do textual para o cultural. Ao mesmo tempo, "as novas possibilidades proporcionadas pela mídia assinalaram caminhos diversos e a distância entre o erudito e o popular foi decisivamente rompida" (COUTINHO, 2007: 30). O que tem sustentado essa mudança é a concepção teórica recorrente na contemporaneidade de que tudo é texto. Postulações como essas, como não poderia deixar de ser, acabaram por contaminar o comparatismo literário, que as tem reelaborado, de forma natural, a partir de sua própria característica de se construir em mobilidade histórica.

\section{COMPARATISMO, INTERTEXTUALIDADE, INTERDISCIPLINARIDADE}

A disciplina Literatura Comparada instituiu-se no quadro teórico das disciplinas já estabelecidas, como sabemos, a partir do desejo cosmopolita de que acolhesse a diversidade. Assim, foi natural que, na evolução desse campo de estudos, a noção de interdisciplinaridade - ainda que o uso do termo no domínio da investigação literária se dê em limite conceitual impreciso, ora tomada como "transdisciplinar" ora entendida como "multidisciplinar" - viesse a repercutir de forma sistemática e metodológica na prática comparatista. No entanto, é bom lembrar que, para isso, foi necessário que a disciplina se transformasse. Isso aconteceu de forma não traumática, sem gerar crises ou grandes abalos epistemológicos - já que, como qualquer disciplina, ela não é mais do que "um conjunto, limitado e construído, de problemas e soluções provisórias" (Cf. Karl Popper, apud CARVALHAL, 2005: 179). Naturalmente, então, a investigação interdisciplinária banalizouse no contexto do comparatismo literário. $\mathrm{O}$ que não se deve perder de 
vista, quando se constata esse fato, é que a produtividade alcançada pela aproximação entre o interdisciplinar e o intertextual veio a problematizar e afinar a própria concepção de interdisciplinaridade. Nessas condições, seria útil atualizar o alerta de Roland Barthes sobre o exercício analíticocomparativo entre disciplinas. Diz ele: "Para se fazer a interdisciplinaridade, não basta tomar um 'assunto' (um tema) e convocar em torno duas ou três ciências. A interdisciplinaridade consiste em criar um objeto novo que não pertença a ninguém. O Texto é, creio eu, um desses objetos" (1988: 99). O que está se postulando aí é a capacidade de invenção e de construção inerente ao interdisciplinar. Assim, como entende Reinaldo Marques, caberia ao investigador

criar novos objetos de conhecimento. Isso pressupõe que os sujeitos do conhecimento sejam desinstalados de seus territórios e se disponham a atravessar suas fronteiras, adotando uma mobilidade que os habilita ao diálogo com outros sujeitos e seus referenciais teóricos (1999: 63).

E é essa localização do comparatismo no espaço dos estudos literários contemporâneos que faz da literatura comparada um campo de questionamento particularmente produtivo para a discussão de problemas que, se tomados em absoluto, dificilmente encontrarão uma formulação epistemológica consequente.

\section{REPRESENTAÇÃO ESTÉTICA E “LUGAR DE MEMÓRIA”}

Comentando a incontornável ressonância do sentido do termo memória no amplo espectro das preocupações do homem no final do século XX, o historiador norte-americano Jay Winter chama a atenção para o fato de que o boom reflete "uma matriz complexa de sofrimento, ativismo político, reivindicações de indenização, pesquisa científica, reflexão filosófica e arte" (2006: 87). Ao localizar no fazer artístico um dos lugares privilegiados para a manifestação da memória, ainda que considerado em sua relação com outras elaborações do espírito humano, Winter ratifica o produto artístico como um possível espaço de conexão entre discurso estético e outros discursos que buscam identificar o sentido da palavra memória. Alertando, ainda, para o fato da quase ubiquidade com que ela é usada, ele anota que a palavra acaba por se constituir como "metáfora para movimentos mais amplos de incerteza quanto a como enquadrar o passado" (2006: 87). Jeanne Marie Gagnebin, contudo, refletindo sobre essa "grande preocupação com 
a questão da memória", e invocando Benjamin, Todorov, Adorno e Ricoeur, no quadro da elaboração filosófica, histórica e política do Holocausto, diz que é preciso transcender a atividade de "comemoração" em detrimento de uma valorização da "rememoração" do passado, a qual significaria

uma atenção precisa ao presente, em particular a estas estranhas ressurgências do passado no presente, pois não se trata somente de não se esquecer do passado, mas também de agir sobre o presente. A fidelidade ao passado, não sendo um fim em si, visa à transformação do presente (2006: 55).

Situando o tema no contexto da representação estética, Rosani Umbach postula que a presença da "memória na literatura" constitui-se na "encenação da memória, de recordações e lembranças em textos literários, os quais dialogam com os discursos da memória de seu contexto de produção", evidenciando o "funcionamento, processos e problemas da memória (individual e coletiva) no campo ficcional, através de procedimentos estéticos" (2008: 12).

Ao aplicar a noção de lieux de mémoire, proposta pelo historiador francês Pierre Nora (1991 apud PINTO, 1998), à literatura de Jorge Luis Borges, entendida por ele como uma "poética da memória", Julio Pimentel Pinto aponta para a possível localização do trabalho da memória em textos de ficção, os quais se situariam na "borda da história" (1998: 306). No domínio desse entendimento, o ofício ficcional de lembrar revelaria o papel inevitável da literatura como "lugar de memória". Para Nora, esses lugares surgem e se sustentam do sentimento de que não há memória espontânea, de que é preciso ativá-la permanentemente. E é por meio da relação pessoal com o passado que ela se revivifica, que pode ser recuperada. Assim, "é sobre o indivíduo, e apenas sobre ele, que pesa, de forma insistente [...], a dificuldade da memória; é em cima de sua relação pessoal com seu próprio passado que repousa a revitalização possível" (NORA, 1991 apud PINTO, 1998: 299). Entretanto, ainda que história e memória tenham como substrato o passado, há diferenças fundamentais entre a forma como ambas lidam com os fatos pretéritos. Uma delas seria a de que a memória situa a lembrança "no espaço do sagrado, do mito, enquanto a história o expulsa". Daí porque, para Nora, a memória seria "múltipla e multiplicável, coletiva, plural e individualizada: um fenômeno sempre atual, um fio vivido no presente eterno" (apud PINTO, 1998: 291). 


\section{A VONTADE do PASSAdo NA INTERSECÇÃo PALAVRA- IMAGEM}

Código estético narrativo por excelência, também o cinema coloca questões importantes para a compreensão dos mecanismos da memória no âmbito da ficção fílmica. Gilles Deleuze, ao analisar a natureza da imagem, propõe situá-la não no tradicional binário imagem-movimento, mas na síntese imagem-tempo, neologismo criado por ele para designar o caráter essencial do cinema pós-guerra. Levando em conta que a memória "é conduta de narrativa", que ela relata o que se passou, e já que o passado "não se constitui depois do presente que ele foi, mas ao mesmo tempo", o filósofo francês diz que é preciso que o tempo "se desdobre a cada instante em presente e passado" (DELEUZE, 1990: 102). Por meio dessa elaboração, a memória não estaria no sujeito, como potência a ser acionada, mas "somos nós que nos movemos numa memória-Ser, numa memória-mundo" (p. 121). Assim, o suposto presente da narrativa fílmica não existiria, a não ser como "um passado infinitamente contraído no presente" (p. 122). A "memória no cinema", então, não seria somente a encenação da memória, de recordações ou lembranças em textos fílmicos, mas a própria manifestação textual de uma memória que se narra no presente.

Por via dessas premissas, seria possível considerar romances, contos, versos, filmes, desenhos, gravuras, fotografias, no que esses objetos estéticos e culturais resultam da migração de um sujeito para além da história, como constituintes e produtos de discursos que se vinculam à consciência de um passado que persiste porque pode ser resgatado por meio de estratégias de representação midiática.

Mesmo que se deva assinalar o evidente princípio de que o trabalho artístico estabelece com a realidade uma relação "deformante e arbitrária", para usar palavras de Antonio Candido, já que, "mesmo quando o intuito da representação seja o da mimesis sempre haverá uma forma de poiesis" (1985: 12), é possível sustentar a vinculação do texto criado ao contexto social a partir da aproximação do trabalho da memória ao exercício de ficcionalização, o qual se construiria como princípio mobilizador da lembrança do vivido no presente da representação. Noutras palavras: a presentificação do passado pela elaboração estética tornaria possível o diálogo da ficção com uma memória que, evocando o passado, garantisse a sua manifestação no presente. É nessa direção também que aponta Rosani Umbach, quando diz, referindo-se aos estudos sobre a encenação literária da memória e seus pressupostos, que "a literatura toma como referência 
a realidade cultural extratextual, inclusive os discursos da memória". Contudo, diz ela, ainda, reafirmando a lição de Antonio Candido (1985), mesmo que esses estudos se baseiem em modelos miméticos da relação memória-literatura, a construção de realidades, no contexto da criação estética, "deve ser entendida no sentido da poiesis, da imitação criadora" (2008: 13).

Ao mesmo tempo, como pondera Beatriz Sarlo, as artes de uma forma geral, e a literatura em particular, não têm o compromisso de "superar todos os lugares comuns do grande relato catastrofista e, simultaneamente, indicar a catástrofe" (2002: 51). Por outro lado, é preciso reconhecer que a representação estética já comprovou que é possível trabalhar o passado, enfocado não de forma global ou totalizante, mas a partir de medos, utopias, fragmentos de histórias e de memórias individuais. No que concerne à representação do fato histórico, especificamente, para além do debate historiográfico, entretanto, permanece o problema: seria possível traduzir em discurso estético acontecimentos que resistem a serem capturados até mesmo pelo discurso explicativo e relativizante da história?

Comentando a eficácia da presentificação estética do Holocausto, no filme Shoah, pelo cineasta Claude Lanzmann, Sarlo recoloca a discussão sobre se fatos históricos podem ser representados - "transladados-traduzidos" - para o discurso. Defendendo a ideia de que, justamente por criar estratégias representativas que não se valem de imagens contemporâneas dos acontecimentos que quer presentificar, nem tampouco da construção de cenários onde personas históricas tornam-se personagens de um roteiro fílmico, o cineasta surpreende, ao rejeitar a atualização de imagens do passado para se fixar nos restos físicos preservados na geografia dos campos de concentração e na linguagem das testemunhas dos fatos. Quando articula a representação fílmica por meio da rejeição de uma "memória visual" centenas de vezes veiculada em todas as tentativas de recuperar historicamente os fatos, Lanzmann comprova que a memória pode emergir dos restos físicos e do ofício de lembrar das testemunhas factuais. Seu texto, narrativa esteticamente elaborada, se constituiria, então, como um desses "lugares de memória" de que nos fala Pierre Nora. Conclui, Sarlo, que "Lanzmann prova que a arte tem um potencial para iluminar aqueles fatos sobre os quais pensamos que sabemos o suficiente" (2002:54). Por essa linha reflexiva, poder-se-ia afirmar que, mais relacionada à representação ficcional do que à representação histórica, a memória, ao atribuir importância a tudo que evoca o passado, assegura a sua permanência no presente, ainda que de forma incompleta e definitivamente irrecuperável: 
Se considerarmos a sociedade, não como uma síntese de interesses que seriam combinados num hipotético fim da história, mas como uma trama de conflitos cuja resolução dá origem a novos conflitos, há um espaço para o pensamento crítico e para a arte [...] como discursos que nos obrigam a depararmo-nos com o incompleto, a morte e a não-reconciliação ou plenitude (SARLO, 2002: 54).

Para Nora, os "lugares de memória" protegem o passado, face a um presente que impossibilita a memória espontânea, pois "quando a memória não está mais em todas as partes, ela não poderia estar em nenhuma se uma consciência individual [...] não se decidisse a retomá-la" (apud PINTO, 1998: 303). Essa memória individualizada no presente, resultante do trabalho de memória do passado, constitui-se como um dever: o de lembrar para recuperar o acontecido. Fatos de um tempo pretérito, então, ainda que escapem à legitimação por meio do discurso estético, podem se constituir em uma forma de memória que, impressa no sujeito, movimenta-se por fluxos e influxos, dialogando com seu passado pessoal e imprimindo-lhe feitios coletivos de compreensão do vivido.

Como se vê, entendendo-se a literatura e, por extensão, toda a narrativa de ficção, inclusive o cinema e, eventualmente, a fotografia, como sendo alguns dos possíveis "lugares de memória" sugeridos por Nora, verifica-se que, a contrapelo de uma história que exorciza a memória, pode manifestarse no discurso estético uma vontade do passado que, mesmo que reconheça seus limites no contexto do tempo presente, não deixa de flutuar por entre as dobras e as bordas da história.

Seria, então, a memória-mundo, atualizada por meio do discurso estético, que possibilitaria a concentração do tempo pretérito num presente inventado. $\mathrm{Ou}$, como propõe Deleuze, um tempo passado “infinitamente contraído no presente" (1990: 102). Essa possibilidade especial de elaboração do passado, resultado da condensação do tempo histórico no presente do indivíduo, diz muito sobre a possibilidade de a arte lidar com conflitos tão esquivos como os provocados pela relação entre saber e não saber, entre lembrar e não lembrar, entre esquecer e não esquecer, entre representar e não representar.

\section{LITERATURA E CINEMA EM TEMPOS DE AUTORITARISMO}

É a partir de duas obras criadas no contexto do autoritarismo brasileiro recente, dois "lugares de memória", um, literário - o conto "Alguma coisa urgentemente", de João Gilberto Noll (1980) -, o outro, fílmico - Nunca fomos tão felizes, de Murilo Salles (1984) -, que passo a refletir sobre a 
relação tempo-memória-representação em textos narrativos de ficção.

Marcadas pelo nacionalismo e pelo experimentalismo do final dos anos sessenta, as artes brasileiras em geral - notadamente a literatura e o cinema - vão enfrentar, nos difíceis anos seguintes ao AI-5, tempos de recrudescimento dos métodos repressivos da ditadura, numa conjuntura de completo fechamento político e de restrição às liberdades individuais. No que respeita à literatura, contudo, os anos setenta veem um verdadeiro boom tanto na produção quanto na circulação e na recepção de textos ficcionais. Surge um impressionante conjunto de novos autores, enquanto outros, vindos da década anterior, firmam-se no cenário literário e cinematográfico. Em grande parte como reação ao autoritarismo, a produção ficcional deu um salto não só quantitativo mas, também, na qualidade textual e na pluralidade de projetos pessoais em busca de novas formas de expressão pela palavra e pela imagem que pudessem neutralizar o sistema repressor e falar com urgência do presente para o presente. Tanto na literatura como no cinema, experimentou-se, até mesmo em níveis de sofisticação, a forma alegórica para figurar os contextos social, histórico e político.

Os textos literário e fílmico de que me ocupo, no entanto, foram criados e postos em circulação já em momento de distensão política e de abertura "lenta, gradual e progressiva", no final dos setenta e início dos oitenta. É o tempo em que se rearticulam os segmentos sociais, em que a censura começa a perder os mecanismos institucionais que a sustentavam, em que a anistia, mesmo que longe de ser ampla, geral e irrestrita, possibilita o retorno dos exilados. A retomada do discurso político direto libera os autores do até então estratégico uso da linguagem alegórica e de sub e intertextos com que se construiu preponderantemente o espaço discursivo no qual se debateu o passado, o presente e o futuro da nação brasileira. Ao mesmo tempo, um outro fluxo literário vai tentar dar conta do vivido pelo veio da presentificação da memória dos recentemente ultrapassados anos de autoritarismo. Nesse impulso pelo qual se buscou recuperar e avaliar o passado recente, é como se os personagens da ficção literária e fílmica, produzida nos últimos dez anos, viessem à cena para cumprir o dever da memória por meio de textos autobiográficos, depoimentos e testemunhos que ganham a dimensão de documento desentranhado dos arquivos do indizível. ${ }^{4}$

\footnotetext{
${ }^{4}$ No final dos anos setenta e início dos oitenta, a partir do governo do general João Batista Figueiredo (1978-1985), quando se dá, gradualmente, o início da "abertura", com a extinção parcial dos atos institucionais e com a promulgação, em 1979, da Lei da Anistia,
} 


\section{A PALAVRA TRUNCADA EM JOÃO GILBERTO NOLL}

Primeiro livro publicado por João Gilberto Noll, em 1980, ${ }^{5}$ O cego e a dançarina ${ }^{6}$ enfeixa vinte e cinco contos. Em pelo menos quatro deles, percebe-se a abordagem diferenciada do cenário sociopolítico dos anos setenta em relação a textos que vieram à luz principalmente a partir de 1975 e que tematizaram, ainda que de forma não realista, a repressão, a tortura física e psicológica, as perseguições e as consequências legais, morais e éticas das restrições ao exercício das liberdades civis. Em "Queda e tiro", o personagem, incapaz de resgatar pela palavra o tempo vivido na prisão da Ilha Grande, não consegue cumprir o dever da memória e se instalar no presente histórico. Em "Ruth", um exilado na Paris do final dos anos setenta vive no limbo da lembrança de um passado brasileiro não resolvido, o qual não lhe permite iluminar o presente. Em "A virgem dos espinhos", a repressão sexual de dois irmãos explode em tragédia durante surto verbal de um deles, militante da organização "Fé pela moral do povo brasileiro". É do quarto conto que se constrói nesse espectro temático - o da importância

que permitiu a volta dos exilados, a libertação dos presos políticos e que possibilitou eleições gerais, ainda que manipuladas, são publicados livros e lançados filmes que buscam reconstituir, pela encenação realista, a catástrofe dos anos antecedentes, os quais são narrados a partir dos testemunhos das vítimas, ou por meio de documentos da pesquisa histórica, encenando com detalhes os atos da repressão, as perseguições, o embate da luta armada, a tortura, o cerceamento das liberdades individuais. Sobre esse período, ver A ditadura derrotada (São Paulo: Companhia das Letras, 2002) de Elio Gaspari. São exemplares, nesse sentido, os textos literários em prosa $O$ que é isso, companheiro? (Fernando Gabeira, 1979), Os carbonários - memórias da guerrilha perdida (Alfredo Sirkis, 1981); e, no texto em verso, o testemunho de Alex Polari de Alverga, Camarim de prisioneiro (1980). No cinema, o exemplar mais representativo dessa tendência é o filme Pra frente, Brasil (Roberto Faria, 1983).

${ }^{5}$ Gaúcho, residente no Rio de Janeiro desde 1969, o escritor assim se refere ao seu "exílio carioca" durante os anos setenta: "Quando cheguei ao Rio, há 15 anos, o que norteava o momento político era a questão da segurança, tanto para o sistema como para os opositores. E eu me senti muito sem pai, muito sem referência política e existencial." Cf. entrevista a Helena Salem, "Com o Leopardo de Bronze de Locarno, chega ao Rio Nunca fomos tão felizes”, no Jornal O Globo (1984).

${ }^{6}$ Numa primeira edição, pela Editora Civilização Brasileira, em 1980, recebeu os prêmios literários: o Jabuti, da Câmara Brasileira do Livro, e o de "Revelação do Ano", da Associação Paulista de Críticos de Artes. Traduzido em vários países, o conto "Alguma coisa urgentemente" foi apontado como um dos melhores do século XX, em Os cem melhores contos brasileiros do século, livro organizado por Îtalo Moriconi (Rio de Janeiro: Editora Objetiva, 2000). 
do relato verbal para a compreensão do vivido -, intitulado "Alguma coisa urgentemente", que me ocuparei na sequência. Escrito "nos primeiros tempos do AI-5", segundo o próprio escritor, o conto foi inspirado em suas experiências "num tempo em que se era privado de saber de coisas" (NOLL apud FLOR, 2008: A7).?

A história das relações entre pai e filho cobre o espaço da primeira infância à adolescência do narrador-personagem, durante o período que vai desde o início dos anos sessenta até meados dos setenta, ápice da repressão política no país. Narrado em primeira pessoa, o conto encena circunstâncias esparsas do relacionamento pai-filho, depois que a mãe abandona marido e o filho único, em Porto Alegre, passando pela segunda infância e chegando à adolescência do personagem sem nome, com o desfecho da trama, no Rio de Janeiro. Por meio de texto decupado por cortes profundos no tempo e no espaço, são presentificados momentos fundamentais na formação do jovem narrador, cobrindo mais ou menos quinze anos de sua existência, a qual coincide com o tempo narrativo do conto. Nos primeiros anos de vida, em passeios na Praça Júlio de Castilhos, o pai

ensinava os nomes das árvores [...], a região de origem [...] dizia que o mundo não era só aquelas plantas, era também as pessoas que passavam e as que ficavam e que cada um tem seu drama. Eu lhe pedia colo. Ele me dava e assobiava uma canção medieval que afirmava ser a sua preferida (p. 11).

Por essa época, o pai lhe prometera que o ensinaria a ler e a escrever: "Quando você aprender a ler vai possuir de alguma forma todas as coisas, inclusive você mesmo" (p. 12). Nesse segmento inicial, correspondente à primeira infância da personagem, identifica-se o que Walter Benjamin apontou como a possibilidade de que uma "tradição compartilhada por uma comunidade humana, tradição retomada e transformada, em cada geração, na continuidade de uma palavra transmitida de pai para filho" (apud GAGNEBIN, 2006: 49-50), pudesse garantir o sentido da existência para muito além das experiências individuais. À perda dessa capacidade de transmissão de experiência fincada na oralidade, Benjamin ajunta

\footnotetext{
7 "A mudança na área da educação marcou o escritor João Gilberto Noll. Estudante de Letras em Porto Alegre à época, ele decidiu deixar a universidade no início de 1969 e se mudar para o Rio. 'Achava o ensino muito cerceador', diz. No Rio, chegou a dar guarida a foragidos políticos. As experiências nos primeiros tempos de AI-5 inspiraram seu primeiro conto, "Alguma coisa urgentemente"' (FLOR, 2008).
} 
ainda um outro desaparecimento, o das formas tradicionais da narrativa, localizando a procedência dessa dupla desaparição nos acontecimentos que culminaram com as sucessivas catástrofes mundiais a partir da Primeira Guerra Mundial. O narrador de Noll, ao localizar não só na palavra oral mas também na prática da escrita e da leitura do mundo a transmissão da imprescindível experiência, acaba por problematizar também a própria escritura que pratica. Vejamos como isso é articulado no texto.

Por corte profundo no tempo e no espaço, depois que o pai é preso no interior do Paraná, acusado de passar armas a um grupo não identificado pelo narrador, o menino encontra-se em um colégio interno em São Paulo. Ali, aprende a ler, a se masturbar e a roubar comida dos padres. No fragmento narrativo seguinte, após outro corte espaciotemporal, vamos reencontrá-lo, já adolescente, quando o pai vai pegá-lo no internato:

Quando cresci, meu pai veio me buscar e ele estava sem um braço [...]. Olhei para o meu pai e disse que eu já sabia ler e escrever.

Então você saberá de tudo um dia - ele falou. (p. 13)

Na sequência, agora instalados no Rio de Janeiro, num apartamento quase vazio da Avenida Atlântica, o narrador insiste com o pai: "Eu quero saber." Face à insistência do garoto, o pai diz: "Não. Pode ser perigoso. Ainda é cedo." E desaparece novamente, deixando o adolescente com algum dinheiro e sem nenhuma possibilidade de tê-lo como narrador do mundo, que agora, mais do que antes ainda, escapava à sua compreensão. Quando o pai volta, está "muito magro, sem dois dentes":

Eu vim para morrer. A minha morte vai ser um pouco badalada pelos jornais, a polícia me odeia, há anos me procura. Vão te descobrir mas não dê uma única declaração, diga que não sabe de nada. O que é verdade. (p. 15)

O trabalho do pai, como voz narrativa da experiência do vivido, de ensinar o mundo ao filho, bem como o cumprimento da promessa de que a leitura da escrita do mundo lhe faria "possuir de alguma forma todas as coisas", são truncados, tornados impossíveis pelas circunstâncias históricas que afastaram um do outro. Dessa forma, perde-se o fio da tradição.

No final do conto, ao adolescente, resta o pai morto, a narrativa do mundo que não se concretizou e o sentimento inútil de que "precisava fazer alguma coisa urgentemente" - última frase da narrativa literária. 
A escrita de João Gilberto Noll resiste a formulações fáceis de encenação realista dos fatos catastróficos, retirando sua força representativa da estratégia de contar nas bordas rarefeitas da história e de suspeitas evidências factuais. Assim, os indícios da catástrofe - o pai sem braço, a ausência, a falta de dentes, enfim, as sobras de um real não alcançado - são apresentados como sinais de um contexto cuja construção escapa ao jovem narrador. A perda da experiência do passado congela o sujeito num presente que não lhe possibilita a transição para um tempo futuro. Trincada ficou a superfície de um mundo em descontinuidade que o pai começara a organizar para o narrador enquanto menino; truncada ficou a história desse mundo.

Inventando um presente narrativo que condensa, em pouco mais de quinze anos, o tempo de não-formação de um indivíduo, Noll instala o narrador, pela impossibilidade de conexão com a memória e a experiência do pai, em estado de impotência para agir sobre o presente. Dessa forma, ainda que ele, o narrador, constate que é "preciso fazer alguma coisa urgentemente", vê-se incapaz de qualquer ato que possa transformar o presente pelo conhecimento do passado.

Lugar de memória (Nora) sobre os anos de autoritarismo, o texto literário constitui-se, assim, como lugar de reflexão e de representação do passado, ainda que se estruture como impossibilidade de restauração de fatos históricos, os quais, por sua vez, só poderiam ser recuperados por meio de uma rememoração ativa do passado por um sujeito que exercitasse a dificuldade da memória por meio de sua relação pessoal com o seu próprio passado. Órfão da palavra do pai e, consequentemente, da possibilidade da memória, resta ao personagem-narrador a incapacidade de agir, cortado que foi da memória o fio que poderia unir o passado ao presente. Interrompese, assim, a trajetória de um homem em direção ao seu futuro.

\section{A IMAGEM FRATURADA EM MURILO SALLES}

Três anos depois da publicação do conto de João Gilberto Noll, o cineasta Murilo Salles traduz a história do jovem narrador sem nome para o cinema. Em plena época de distensão política, a campanha das eleições diretas está nas ruas, o país vive a euforia de uma democracia quase renascida. Retornando de um autoexílio em Moçambique, onde lecionou cinema e fotografia e realizou o documentário Essas são as armas (1978), para a Frente de Libertação de Moçambique - FRELIMO, Salles lê o livro de Noll e decide traduzir o conto "Alguma coisa urgentemente" em imagens 
fílmicas. ${ }^{8}$ Concebido e realizado entre 1982 e 1983, o filme estreia em 1984, com o título de Nunca fomos tão felizes. ${ }^{9}$

A película surge num momento em que a indústria cultural, colocando no mercado midiático uma grande quantidade de produtos relacionados à catástrofe nacional pós-golpe de 64, procura fazer do traumatismo um ponto de venda. Na contracorrente dessa exploração do trauma, Murilo Salles se coloca "contra" a representação do horror por meio da reconstituição dos atos e dos fatos de forma "realista" mas não correspondente ao "real", que se sabe, de qualquer forma, ser irrecuperável. Se Noll optara por não explicitar a encenação, de forma realista-naturalista, dos acontecimentos relacionados às lutas de guerrilha urbana nos anos setenta, como vimos, preferindo localizá-los em algumas marcas textuais de sua narrativa, transitando pelas bordas e dobras da história, Salles adota a mesma linha memorialista. Seu filme reescreve o texto literário como "rememoração" do passado, formalizando-o não como uma tentativa de erigir em heróis

\footnotetext{
${ }^{8}$ Para ele, o texto literário é uma "metáfora sobre as relações dos brasileiros com a guerrilha urbana dos anos 70" (Cf. NAGIB, 2002: 411) e o seu filme capta "esse medo que estava no ar, a solidão também" (Cf. SALEM, 1984: 1).

${ }^{9}$ Direção: Murilo Salles. Argumento: João Gilberto Noll. Roteiro: Alcione Araújo, Murilo Salles e Jorge Duran. Fotografia: José Tadeu Ribeiro. Montagem: Vera Freira. Música: Sergio Saraceni. Elenco: Cláudio Marzo (o pai), Roberto Bataglin (o filho), Suzana Vieira, Meiry Vieira. Produção: Embrafilme/Salles\&Salles, L.C. Barreto. Distribuição: Embrafilme. 1h30, color. Estreou no Festival de Cannes de 1984 e foi apresentado no Festival de Locarno, onde recebeu o Leopardo de Bronze de Melhor Filme. No Festival de Cinema de Brasília, o prêmio de melhor filme para o júri oficial e de público. O título alude a um slogan difundido pela Televisão Globo na década de 70: "Nunca fomos tão felizes". $\mathrm{Na}$ abertura do filme - paratexto que pode ser considerado como um incipit para o texto narrativo que se segue -, explicita-se a intenção crítica do autor fílmico: o título - Nunca fomos tão felizes - aparece dividido em duas linhas, com graficação diferenciada para as duas metades da frase-paratexto. Primeiro, aparece "tão felizes", em letras com traços largos retilíneos; depois, "nunca fomos", com letras traçadas por linhas finas e curvas. Quando o filme termina, repete-se o título, fazendo as vezes da palavra FIM: mas, dessa vez, possibilitando leitura ambígua, já que se inverte a forma de apresentação das duas partes do título, com o acréscimo de ponto de exclamação depois de "tão felizes!". O título, no conjunto das duas partes, pode ser lido então assim: Tão felizes! Nunca fomos. Opõe-se, dessa forma, ao sentido primeiro com que a propaganda da ditadura veiculou a expressão, em épocas de "esse é um país que vai pra frente" e "Brasil, ame-o ou deixe-o". Ao invés de sugerir que éramos mais felizes do que nunca, o jogo visual da variação gráfica o que dizia é que nunca fomos felizes. O cartaz de divulgação do filme na época do lançamento, bem como a caixa do filme em VHS, de 1988, repetem essa fórmula no layout do título, com pequenas variações de design.
} 
ficcionais as vítimas da repressão, mas como um trabalho de memória que, evidenciando sua fidelidade ao passado, visa à transformação do presente. É o que buscarei mostrar na continuidade desta reflexão.

$\mathrm{Na}$ transposição de um texto literário - o qual se vale da qualidade de abstração possibilitada pela palavra para construir a impressão de realidade - para outro código narrativo - que se articula por meio de imagens montadas em sequência, e que, por definição, trabalha com a presentificação de um real imaginário -, o cineasta teve que decidir sobre o que mostrar e o que deixar de fora de seu enquadramento para a narrativa verbal. Elidindo o importante segmento inicial do conto, em que o narrador apresenta sua relação com o pai no período de suas vidas em que o mundo começava a ser contado pela palavra da experiência do pai, o narrador fílmico - le grand imagier ${ }^{10}$ - opta por começar a narrativa no momento em que o pai vai buscar o filho internado no colégio dos padres, antes de instalá-lo no apartamento deserto em Copacabana e desaparecer novamente, até sua volta para morrer mudo da palavra-garantia do sentido do mundo. É no espaço-tempo de um labiríntico e quase vazio apartamento (mas repleto de espelhos e imensas janelas envidraçadas que nunca são abertas) que o narrador fílmico traduz em imagens a impossibilidade de construção de um presente para o adolescente, impedido, assim, de "possuir de alguma forma todas as coisas, inclusive ele mesmo" (NOLL: 13).

E que imagens de Salles são essas que traduziriam a intenção da palavra literária em Noll? O cineasta precisa inventar no processo de transcriação. São essas invenções tradutoras que garantem a eficácia da reescritura de Noll por Salles. Atualizemos algumas. Na sequência inicial, o adolescente é entregue ao pai pelo pai-padre-diretor do colégio onde ele aprendeu a ler uma outra história, por meio de outras memórias que não se articulam com a história do mundo que o pai apenas começara a lhe contar. O enquadramento, nessa primeira sequência fílmica, é dominado por uma imagem de Nossa Senhora, a mãe-símbolo de uma outra ausência, que

\footnotetext{
${ }^{10}$ Para Albert Laffay (1964: 81, tradução minha), "o narrador fílmico é aquela presença virtual escondida atrás de todos os filmes: le grand imagier". André Gaudreault (1988: 11), ampliando a proposta de Laffay, sugere a seguinte comparação para o estatuto dos dois narradores: "Récit scriptural: auteur (écrivain), auteur implicite, abstrait, narrateur scriptural; récit filmique: auteur (cinéaste), le grand imagier, narrateur filmique, articulateur du plan à plan, montateur." Como se vê nessa articulação, são apagadas as diferenças de códigos para que permaneçam definidas as figuras do narrador literário (narrateur scriptural) e do narrador fílmico (narrateur filmique, le grand imagier).
} 
paira sobre a cena. Tão logo chegam ao apartamento, instado várias vezes pelo filho, o pai insiste em que não pode lhe contar, que é perigoso. Depois, o vazio do campo imagético: os espelhos, em que se reflete a imagem do adolescente na qual ele não se reconhece; a máquina fotográfica que ele usa para fixar imagens do nada; as imagens da televisão com as quais não consegue se conectar, pulando de um canal para outro; a fotografia de um guerrilheiro morto na primeira página de um jornal largado pelo pai, sem comentários, sobre uma mesa vazia; a foto de uma mulher, encontrada em uma das gavetas vazias, que ele olha detidamente, tentando alguma conexão com o seu imaginário em busca de sentido para um pedaço de memória, e a qual ele cola na vidraça de uma janela sobre o vazio, antes de, num gesto de desespero pelo não entendimento, esmurrar o vidro, quebrando a vidraça que dá para um imenso e inútil céu vazio: por trás da imagem não há outra imagem, não há sucessão de imagens que possam manter íntegro o fio da memória, unindo o passado ao presente, justificando-o pela presentificação das imagens.

Uma outra invenção tradutora fundamental, criada pelo cineasta, é a de uma sequência em que, logo após a chegada ao apartamento, na única vez em que saem juntos, pai e filho estão em um cinema, onde, como em tantas outras narrativas fílmicas, dois personagens podem conversar, fazer revelações mútuas, especialmente em filmes em que, sentindo-se tolhidos pelo ambiente, se imaginam seguros para troca de informações. A cena é especialmente criativa no que ela tem de interpretação e recriação de sentido para a história literária de Noll e serve a Salles para que ele comente a relação do cinema - ou da imagem - com a história recente do país, com a própria história que narra e com a história enquanto discurso que tenta dar conta do passado por meio da relativização analítica e crítica dos acontecimentos (Nora). Vejamos como é construído o segmento: em primeiro plano, as silhuetas de pai e filho, recortados de costas, em plano geral, sobre a tela do cinema. Conversam, a meia-voz, por palavras soltas que se perdem antes de chegarem ao ouvido do espectador. Percebe-se que o tema é a luta armada contra a ditadura. Desfocadas, na profundidade de campo do quadro fílmico, aparecem imagens do filme Os inconfidentes (1972), ${ }^{11}$ de Joaquim

${ }^{11}$ Direção: Joaquim Pedro de Andrade. Roteiro: Joaquim Pedro de Andrade e Eduardo Escorel, com diálogos baseados em versos de O romanceiro da inconfidência, de Cecília Meirelles, de poemas de Tomaz Antonio Gonzaga, Cláudio Manoel da Costa e Alvarenga Peixoto e de trechos dos Autos da Devassa. Fotografia: Pedro de Moraes. Montagem: 
Pedro de Andrade, em que Tiradentes e Maciel falam em libertar o país da colônia portuguesa. Nas telas do país em 1972, o filme insere-se no esforço da cinematografia da época para tentar dar conta do presente pela invocação de fatos da história do Brasil. Ou seja, por meio de linguagem alegórica, buscava-se comentar o presente em tempos de censura institucionalizada. Fato que deve ser evidenciado, contudo, é o de que o filme Os inconfidentes pode ser visto como um trabalho de "rememoração", na medida em que transcende a atividade da "comemoração" de fatos históricos; quer dizer, que busca "uma atenção precisa do presente", pois, como vimos, "não se trata somente de não se esquecer do passado, mas também de agir sobre o presente" (GAGNEBIN, 2006: 55). Nessa direção, o filme de Joaquim Pedro de Andrade é exemplar, se atentarmos para o fato de que, na última sequência, é inserido material de cine-jornal da época, o qual, por meio de imagens "verdadeiras", reporta as comemorações oficiais de 21 de abril na cidade de Ouro Preto, em 1971. Precisamente ao final da encenação do enforcamento de Tiradentes, centenas de colegiais uniformizados aplaudem a apoteose cívica, sob a fanfarra de bandas marciais. Sobre essas imagens documentais, o final da narrativa de Os inconfidentes: aparece a palavra FIM.

O uso metalinguístico da imagem fílmica, por meio de exercício intertextual em que a memória do cinema comparece para significar o presente na narrativa de Nunca fomos tão felizes, ainda aparecerá na última sequência do filme, quando, enquanto o pai morre - o filho ao seu lado, sem ouvir de sua boca qualquer palavra -, pode-se ver na tela da televisão uma cena do filme Vidas amargas (East of Eden, Elia Kazan, 1954), tradução fílmica do romance de John Steinbeck. Nessa cena de Nunca fomos tão felizes como na de Vidas amargas, ambos os filhos estão ao lado do pai que morre. O que faz Murilo Salles é colar imagens da memória cinematográfica como lembranças que se concentram em um só presente imagético: por meio dos fotogramas de Joaquim Pedro em Os inconfidentes e dos de Kazan em Vidas amargas, pai e filho de Nunca fomos tão felizes falam em silêncio de coisas que, ainda que não os reconciliem com o necessário movimento intermitente do fio da memória, na construção de um presente para o jovem, possibilitam ao

Eduardo Escorel. Música: Ari Barroso, Marlos Nobre, Agustín Lara. Elenco: José Wilker (Tiradentes), Paulo César Peréio (Alvarenga), Fernando Torres (Cláudio), Luis Linhares (Gonzaga). Produção: Filmes do Serro, Grupo Filmes e Mapa Filmes. Distribuição: Mapa. 1h51, color. 
espectador produzir sentido para o que vê, no contexto da cena brasileira do início dos anos setenta. Assim, como quer Gilles Deleuze, o "tempo se desdobra a cada instante em presente e passado", ou seja, em passado "infinitamente contraído no presente" (1990: 102). Pela dupla prática intertextual de Murilo Salles, comprovar-se-ia que, conforme explicitei antes, o trabalho da memória no cinema não seria somente a encenação da memória de recordações ou lembranças, mas a própria manifestação de uma memória que se narra no presente.

Ainda um último comentário sobre o final do filme: no instante em que o pai morre, o filho pega a câmara fotográfica tipo polaroide e congela a definitiva ausência em imagem. $O$ retrato do pai-mudo da palavra, conduta da experiência, atualiza, irreversivelmente, o desamparo do adolescente, homem truncado em um presente que não lhe permite a perspectiva de futuro, desamparado ainda que está por um "Estado de não-Direito" - como todo cidadão-adolescente sob a ditadura civil-militar dos anos setenta -, sem a garantia do exercício de suas liberdades individuais.

\section{CONCLUSÃO}

No momento em que me encaminho para o fechamento desta reflexão sobre o tema do trabalho da memória por meio da representação estética - que considerou a questão no entrecruzamento de trânsitos midiáticos -, é preciso retomar as considerações de Beatriz Sarlo, quando ela afirma que é preciso reconhecer que as artes já comprovaram que é possível trabalhar o passado, enfocando-o não de forma totalizante, mas a partir de utopias, fragmentos de histórias e memórias individuais. Não é isto, afinal, o que atestam as narrativas de Noll e de Salles? Por outro lado, as representações literária e fílmica, lidas em conjunto ou separadamente, podem ser reconhecidas como aquilo que Pierre Nora denominou de "lugares de memória": textos que exercitam o ofício ficcional de lembrar. Revelando o papel inevitável das artes como sendo o de traduzir em discurso estético acontecimentos que resistem à apreensão, até mesmo pelo discurso explicativo e relativizante da história (SARLO, 2002: 51), tais elaborações se qualificam como objetos nada negligenciáveis no âmbito da discussão sobre as relações entre tempo histórico, tempo narrativo, memória e representação histórica e estética. Ainda mais quando se trata de pensar o passado como rememoração, como "uma atenção precisa ao presente", como fizeram João Gilberto Noll e Murilo Salles. Eis que, como postula Jeanne Marie Gagnebin, o discurso rememorativo fortalece-se com 
a invocação de uma felicidade do presente. Dessa forma, "ouvir o apelo do passado significa também estar atento a esse apelo de felicidade e, portanto, de transformação do presente, mesmo quando ele parece estar sufocado e ressoar de maneira quase inaudível" (2006: 12).

Literatura e cinema, meios narrativos por excelência, possibilitam, dessa forma, como se viu no andamento desta leitura comparada do conto de Noll com o filme de Salles, que o cineasta, ao transitar do texto alheio para o próprio, explora opacidades e porosidades textuais e, ultrapassando margens e limites semiológicos, na tradução fílmica que propõe para o conto, considera o contexto social e histórico como uma trama de conflitos cuja resolução dá origem a novos conflitos. Nesse intervalo, como pondera Beatriz Sarlo, "há um espaço para o pensamento crítico e para a arte [...] como discursos que nos obrigam a depararmo-nos com o incompleto, a morte e a não-reconciliação ou plenitude" (2002: 54). Esse é um exercício de tradução criativa, sem dúvida, com marca autoral: transcriação. Livro e filme podem ser lidos, então, em conjunto, como textos complementares, numa intersecção em que um ilumina o outro; ainda que, em sua essência formal, constituam-se como objetos midiáticos autônomos, intransferíveis que são em suas especificidades estéticas.

\section{REFERÊNCIAS BIBLIOGRÁFICAS}

BARTHES, Roland. Jovens pesquisadores. In: BARTHES, Roland. $O$ rumor da língua. Trad. Mário Laranjeira. São Paulo: Brasiliense, 1988.

BARTHES, Roland. S/Z: uma análise da novela Sarrasine de Honoré de Balzac. Trad. Léa Novaes. Rio de Janeiro: Nova Fronteira, 1992.

CAMPOS, Haroldo de. A arte no horizonte do provável. São Paulo: Perspectiva, 1969.

CANDIDO, Antonio. Literatura e sociedade: estudos de teoria e história literária. São Paulo: Ed. Nacional, 1985.

CARVALHAL, Tania. Encontros na travessia. Revista Brasileira de Literatura Comparada, Porto Alegre, n. 7, p. 169-182, 2005.

CLERC, Jeanne-Marie. Écrivains et cinéma. Paris: Klincksieck, 1985.

CLERC, Jeanne-Marie. Littérature et cinéma. Paris: Nathan, 1993. 
CLÜVER, Claus. Estudos interartes: conceitos, termos, objetivos. Literatura e Sociedade, São Paulo, n. 2, p. 37-55, 1997.

COUTINHO, Eduardo. A literatura comparada e a Weltanschauung pós-moderna. Revista Brasileira de Literatura Comparada, Porto Alegre, n. 7, p. 25-37, 2005.

DELEUZE, Gilles. A imagem-tempo. Trad. Eloísa Araújo Ribeiro. São Paulo: Brasiliense, 1990.

FLOR, Ana. Ato baixou um silêncio mortal na sociedade. Folha de São Paulo, Brasil Especial, p. A7, 13 dez. 2008.

GADAMER, Hans-Georg. Verdade e método: traços fundamentais de uma hermenêutica filosófica. Trad. Flávio Meurer. 4. ed. Petrópolis: Vozes, 2003.

GAGNEBIN, Jeanne Marie. Memória, história, testemunho; O que significa elaborar o passado? In: GAGNEBIN, Jeanne Marie. Lembrar escrever esquecer. São Paulo: Editora 34, 2006. p. 49-57; p. 97-106.

GAUDREAULT, André. Du littéraire au filmique: système du récit. Paris: Méridiens, 1988.

GENETTE, Gérard. Palimpsestes: la littérature au second dégrée. Paris: Seuil, 1982.

LAFFAY, Albert. Logique du cinéma. Paris: Masson, 1964.

MARQUES, Reinaldo. Literatura comparada e estudos culturais: diálogos interdisciplinares. In: CARVALHAL, Tania (Org.). Culturas, contextos e discursos: limiares críticos no comparatismo. Porto Alegre: EDURFGS, 1999. p. 58-67.

METZ, Christian. Linguagem e cinema. Trad. Marilda Pereira. São Paulo: Perspectiva, 1980.

NAGIB, Lucia. O cinema da retomada. São Paulo: Editora 34, 2002.

NOLL, João Gilberto. O cego e a dançarina [1980]. Porto Alegre: L\&PM, 1986. 
PERRONE-MOISÉS, Leyla. Desconstruindo os estudos culturais. In: CONGRESSO DA ASSOCIAÇÃO PORTUGUESA DE LITERATURA COMPARADA, 4. Anais... Évora, Portugal: Universidade de Évora, 2001.

PINTO, Julio Pimentel. Uma memória do mundo: ficção, memória e história em Jorge Luis Borges. São Paulo: Estação Liberdade/FAPESP, 1998.

SALEM, Helena. Com o Leopardo de Bronze de Locarno, chega ao Rio Nunca fomos tão felizes. Jornal O Globo, Segundo Caderno, 27 ago. 1984.

SARLO, Beatriz. A literatura na esfera pública. Trad. Adriana Silvina Pagano In: MARQUES, Reinaldo; VILELA, Lucia Helena (Org.). Valores: arte, mercado, política. Belo Horizonte: Editora UFMG/Abralic, 2002. p. 37-55.

SCHMIDT, Rita. A literatura comparada nesse admirável mundo novo. Revista Brasileira de Literatura Comparada, Porto Alegre, n. 11, p. 1138, 2007.

SERCEAU, Michel. Ladaptation cinématographique des textes littéraires. Liège, Belgique: Céfal, 1999.

UMBACH, Rosani. Memórias da repressão e literatura: algumas questões teóricas. In: UMBACH, R. (Org.). Memórias da repressão. Santa Maria: UFSM, PPGL Editores, 2008. p. 11-22.

VANOYE, Francis. Récit écrit, récit filmique. Paris: Nathan, 1989.

WINTER, Jay. A geração da memória: reflexões sobre o "boom da memória" nos estudos contemporâneos de história. Trad. Claudia Valladão de Mattos. In: SELIGMAN-SILVA, M. (Org.). Palavra e imagem: memória e escritura. Chapecó: Argos, 2006. p. 67-90. 